\title{
Characterization of receptors for growth hormone-releasing hormone in human osteosarcomas and Ewing's sarcomas
}

\author{
GABOR HALMOS ${ }^{1,2,3}$, ANDREW V. SCHALLY ${ }^{1,2}$, ANDREA L.F. BERNARDINO ${ }^{1,2}$ and JOZSEF L. VARGA ${ }^{1,2}$ \\ ${ }^{1}$ Endocrine, Polypeptide and Cancer Institute, Veterans Affairs Medical Center and ${ }^{2}$ Department of Medicine, \\ Tulane University School of Medicine, New Orleans, LA 70112, USA; ${ }^{3}$ Department of Biopharmacy, \\ University of Debrecen, School of Pharmacy, H-4032 Debrecen, Hungary
}

Received August 30, 2005; Accepted February 3, 2006

\begin{abstract}
Antagonists of growth hormone-releasing hormone (GH-RH) inhibit growth of various human cancers including osteosarcomas and Ewing's sarcomas, xenografted into nude mice or cultured in vitro. The antiproliferative effect of GH-RH antagonists could be mediated, in part, through the splice variants (SVs) of receptors for GH-RH which have been found in several human cancers and cancer cell lines. In this study we investigated the expression of SVs of GH-RH receptors and the binding characteristics of these receptor isoforms in MNNG/HOS human osteosarcoma and SK-ES-1 human Ewing's sarcoma grown in nude mice. RT-PCR revealed the presence of mRNA for SVs of GH-RH receptors in both human malignant bone cancer models. Using ligand competition assays with ${ }^{125}$ I-labeled GH-RH antagonist JV-1-42, we demonstrated in MNNG/HOS and SK-ES-1 tumors the presence of specific high affinity binding sites for $\mathrm{GH}-\mathrm{RH}\left(\mathrm{K}_{\mathrm{d}}=5.83 \mathrm{nM}\right.$ and $\mathrm{K}_{\mathrm{d}}=2.76 \mathrm{nM}$ ) with a maximal binding capacity $\left(\mathrm{B}_{\max }\right)$ of $552.1 \mathrm{fmol} / \mathrm{mg}$ protein and $371.9 \mathrm{fmol} / \mathrm{mg}$ protein, respectively. We also investigated the effect of GH-RH antagonist JV-1-38, administered s.c. at a dose of $20 \mu \mathrm{g}$ twice daily for 4 weeks on the gene expression, affinity and concentration of receptors for GH-RH in MNNG/HOS human osteosarcomas xenografted into nude mice. Treatment with JV-1-38 did not affect the expression and binding characteristics of GH-RH receptors. High affinity binding of JV-1-38 to GH-RH receptors on MNNG/HOS tumors was characterized by an $\mathrm{IC}_{50}$ value of $1.04 \mathrm{nM}$. The presence of GH-RH receptors in human bone tumors provides a rationale for new approaches to the therapy of this malignancy based on GH-RH antagonists.
\end{abstract}

Correspondence to: Dr Gabor Halmos, Department of Biopharmacy, University of Debrecen, School of Pharmacy, Nagyerdei krt. 98, H-4032 Debrecen, Hungary

E-mail: halmos@king.pharmacol.dote.hu

Key words: GH-RH receptors, splice variant, human malignant bone tumors, GH-RH antagonists

\section{Introduction}

Osteogenic sarcomas and Ewing's sarcomas represent the most common primary bone tumors in children and young adults (1-6). Surgery, radiation and high-dose chemotherapy are of limited effectiveness (1-3). Despite aggressive treatment that can improve overall survival (4), many patients develop recurrent disease and metastases (5). Thus, most patients with either localized or metastatic disease ultimately die of these malignancies. Consequently, new therapeutic approaches have to be developed for the management of osteosarcomas and Ewing's sarcomas.

Over the past decade, various investigations demonstrated the role of neuropeptides and growth factors, synthesized locally by the tumor cells or derived from the systemic circulation in promoting the proliferation of human cancers $(2,7-9)$. The role of endocrine and autocrine-paracrine stimulatory loops mediated by insulin-like growth factors I and II (IGF-I and IGF-II) has been demonstrated in the pathogenesis and progression of human osteosarcomas and other malignancies $(2,3,8-10)$. In view of these findings, novel therapeutic strategies that can block or down-regulate various components of the IGF system are being developed by various groups including ours $(2,9,11)$.

Several series of antagonistic analogs of growth hormonereleasing hormone (GH-RH) were synthesized in our laboratory in the past 10 years in an endeavor to develop a new class of antitumor agents $(2,11-14)$. We have shown that these GH-RH antagonists inhibit the growth of various experimental human cancers such as pancreatic (15), colorectal (16), prostatic (17-19), breast $(20,21)$, ovarian (22), renal (23) cancers, glioblastomas (24), osteosarcomas and Ewing's sarcomas $(3,10)$, small cell lung carcinomas (SCLC) and non-SCLC (25-27). $\mathrm{GH}-\mathrm{RH}$ antagonists can suppress tumor growth though indirect and direct pathways. The indirect endocrine mechanism operates through the suppression of the GH release from the pituitary, and the resulting reduction in the hepatic production of IGF-I $(2,11)$. An inhibition of experimental renal, prostatic, SCLC, NSCLC and bone tumors, achieved with relatively high doses of early GH-RH antagonists, was associated with a decrease in hepatic and serum IGF-I levels (reviewed in refs. 2,11). IGF-I is a well-known mitogen for various cancers (9) and thus the decrease in the serum level of IGF-I is likely to 
contribute to the inhibition of tumor growth. However, in other in vivo studies in which we used lower doses of recently developed GH-RH antagonists, such as JV-1-36, JV-1-38 and MZ-J-7-118, the growth of human pancreatic, colorectal, prostatic, breast, ovarian and lung cancers could be inhibited in the absence of any significant effects on serum IGF-I $(15,16,21,22,26,27)$. In addition, it was also observed that GH-RH antagonists inhibit the proliferation of various cancer lines including MNNG/HOS human osteosarcoma and SKES-1 Ewing's sarcoma by a direct action in vitro, under conditions where the contribution of the hypothalamic GH-RH/ pituitary GH/hepatic IGF-I axis is clearly excluded $(20,21$, $26,28,29)$. These findings led to the conclusion that the main mechanism responsible for tumor inhibition could be due to a direct action of GH-RH antagonists on the tumor tissue (2). Such an action would have to be mediated through specific GH-RH receptors on tumors. Our recent investigations demonstrated that surgical specimens of various human cancers and diverse human experimental cancer lines express mRNAs encoding four splice variants (SV) of GH-RH receptors and display specific, high affinity binding sites for GH-RH and its antagonistic analogs (30-33). The isolation and sequencing of cDNA encoding the SVs of GH-RH receptors on these human tumors showed that they are distinct from the pituitary GH-RH receptors $(30,31)$. Among these truncated forms of GH-RH receptors, SV1 displays the greatest similarity to the pituitary GH-RH receptor (31). We also demonstrated the activation of cell proliferation responses to $\mathrm{GH}-\mathrm{RH}$ analogs in 3T3 fibroblasts transfected with the SV1 isoform of GH-RH receptors (34), supporting the hypothesis that SV1 mediates direct effects of GH-RH and its analogs in human tumors.

Our previous study in nude mice bearing MNNH/HOS osteosarcomas and SK-ES-1 Ewing's sarcomas revealed that treatment with GH-RH antagonist JV-1-38 significantly inhibits growth of these malignant human bone tumors (3). In proliferation studies in vitro, the growth of MNNG/HOS and SK-ES-1 cells was dose-dependently inhibited by JV-1-38 and the expression of mRNA for GH-RH and SVs of GH-RH receptors was also found in these sarcoma lines (29).

The aim of the present study was to investigate the expression of SVs of GH-RH receptors and the binding characteristics of the GH-RH receptor isoform in MNNG/ HOS and SK-ES-1 human malignant bone tumors. We also examined whether GH-RH antagonist JV-1-38 administered s.c. at a dose of $20 \mu \mathrm{g}$ twice daily for 4 weeks would affect the gene expression and binding characteristics of receptors for GH-RH on cell membranes of MNNG/HOS tumors. In addition, we evaluated the receptor binding affinity of GH-RH antagonist JV-1-38 in MNNG/HOS human osteosarcomas.

\section{Materials and methods}

Peptides and chemicals. GH-RH antagonists JV-1-38 and JV-1-42 were synthesized by solid phase methods, and purified and analyzed as described previously (13). Radioisotope ${ }^{125}$ I-labeled sodium was purchased from Amersham Pharmacia Biotech (Piscataway, NJ). All other peptides and chemicals, unless otherwise mentioned, were obtained from SigmaAldrich (St. Louis, MO), Bachem (Torrance, CA), and R\&D Systems, Inc. (Minneapolis, MN).
Radioiodination. Iodinated derivatives of GH-RH antagonist JV-1-42 were prepared by the Cloramine-T method as described and purified by HPLC (32). The fractions corresponding to the mono-iodinated compound and identified by elution position, radioactivity, and UV peak, were stored at $-70^{\circ} \mathrm{C}$ for the in vitro receptor studies.

Cell lines. MNNG/HOS human osteosarcoma cell line (35) and SK-ES-1 cell line, originating from a Ewing's sarcoma (36) were obtained from the American Type Culture Collection (Manassas, VA). MNNG/HOS was grown as a monolayer in minimal essential medium supplemented with $10 \%$ fetal bovine serum and antibiotics, and antimycotics $(100 \mathrm{U} / \mathrm{ml}$ penicillin $\mathrm{G}$ sodium, $100 \mu \mathrm{g} / \mathrm{ml}$ streptomycin and $0.25 \mu \mathrm{g} / \mathrm{ml}$ amphotericine B) (3). All culture media components were purchased from Gibco (Gaithersburg, MD). SK-ES-1 was grown as a monolayer in McCoy's 5A medium supplemented with $15 \%$ fetal bovine serum and antibiotics and antimycotics as described above (3). Cultures were incubated in air containing $5 \% \mathrm{CO}_{2}$ at $37^{\circ} \mathrm{C}$. Tumor cells growing exponentially were harvested by a brief incubation with $0.25 \%$ trypsin-ethylenediamine tetraacetic acid (EDTA) solution (Gibco).

Animals and tumors. Male athymic nude mice, approximately 6 weeks old on arrival, were purchased from the Frederick Cancer Research Facility of the National Cancer Institute (Frederick, MD) and housed in laminar airflow cabinets under pathogen free conditions with $12 \mathrm{~h}$ light $/ 12 \mathrm{~h}$ dark schedule. Xenografts of each cell line were initiated by subcutaneous injections of $1 \times 10^{7}$ cells into three nude mice (3). After 4 weeks, the tumors from donor animals were dissected aseptically and $3 \mathrm{~mm}^{3}$ tumor pieces were transplanted subcutaneously with a trocar needle into nude mice under isoflurane anesthesia (3). One week after the transplantation, when MNNG/HOS tumors had grown to approximately $50 \mathrm{~mm}^{3}$, mice were divided randomly into two groups and received treatment with GH-RH antagonist JV-1-38 (20 $\mu \mathrm{g}$ subcutaneously twice daily) or vehicle solution (control group) (3). After 4 weeks of treatment, the mice were sacrificed, and MNNG/HOS tumors were dissected, snap frozen and stored at $-70^{\circ} \mathrm{C}$ for receptor analyses. Four weeks after the transplantation of SK-ES-1 tumors, mice were also sacrificed and the tumors were dissected, snap frozen and stored as described above. All experiments were performed in accordance with institutional guidelines for the care and use of experimental animals.

RNA extraction and RT-PCR analysis of expression of $G H-R H$ receptor splice variants in tumor tissue. Total RNA from subcutaneously grown MNNG/HOS and SK-ES-1 tumors was extracted with Tri-Reagent (Sigma) according to the manufacturer's protocol. Total RNA (4-600 $\mu \mathrm{g}$ ) was further purified with the MicroPoly(A)PURE Kit (Ambion, Austin, TX). The concentration of mRNA was determined spectrophotometrically at $260 \mathrm{~nm}$. Poly(A) RNA $(1 \mu \mathrm{g})$ was reversetranscribed into cDNA with the oligo(dT16) primers and with the reagents of the PCR Core Kit (Applied Biosystems, Foster City, CA) following the instructions of the manufacturer. cDNA for the SVs was amplified by gene specific primers according to the nested PCR protocol previously described $(29,30,32,33)$, except for transferring $1 \mu 1$ of the first PCR 
product to the second PCR without dilution. The PCR amplification of the cDNA for human $\beta$-actin was performed as described (32). PCR products were separated on $1.5 \%$ agarose gel followed by ethidium bromide staining and visualized under UV light. The developed bands were captured with a Kodak DC290 digital camera and pictures were analyzed with the Kodak 1D Image Analysis software (Eastman Kodak Company, Rochester, NY). Relative mRNA levels of each gene were normalized versus the corresponding levels of human $\beta$-actin.

Preparation of tumor membranes. Preparation of membranes from xenografts of MNNG/HOS and SK-ES-1 cell lines grown in nude mice was performed as described previously, with some modifications $(30,32)$. Briefly, the samples were thawed and then the tumor samples were homogenized in $50 \mathrm{mM}$ Tris- $\mathrm{HCl}$ homogenization buffer $(\mathrm{pH} 7.4)(30,32)$, supplemented with protease inhibitors $(0.25 \mathrm{mM}$ phenylmethylsulfonyl fluoride, $2 \mu \mathrm{g} / \mathrm{ml}$ Pepstatin A and $0.4 \%$ Aprotinin) using an Ultra-Turrax tissue homogenizer (IKA Works, Wilmington, NC) for $5 \times 5 \mathrm{sec}$ strokes on ice. The homogenate was centrifuged at $500 \mathrm{x}$ g for $10 \mathrm{~min}$ at $4^{\circ} \mathrm{C}$ to remove nuclear debris and lipid layer. The supernatant containing the crude membrane fraction was centrifuged in a Beckman L8-80M ultracentrifuge twice at 70,000 x $\mathrm{g}$ for $50 \mathrm{~min}$ at $4^{\circ} \mathrm{C}$ after resuspending in fresh buffer. The final pellet was resuspended in homogenization buffer and stored at $-70^{\circ} \mathrm{C}$ until assayed. Protein concentrations were determined by the method of Bradford using a Bio-Rad protein assay kit (Bio-Rad Laboratories, Hercules, CA).

Radioligand binding studies. GH-RH receptor binding assays were carried out as reported in detail, using in vitro ligand competition assays based on binding of [ $\left.{ }^{125} \mathrm{I}\right] \mathrm{JV}-1-42$ as radioligand to tumor membrane fractions $(30,32)$. In brief, membrane homogenates containing 60-120 $\mu \mathrm{g}$ protein were incubated in duplicate or triplicate with $60-80,000 \mathrm{cpm}$ [125 I]JV-1-42 and increasing concentrations $\left(10^{-12}-10^{-6} \mathrm{M}\right)$ of non-radioactive peptides as competitors in a total volume of $300 \mu \mathrm{l}$ of binding buffer ( $50 \mathrm{mM}$ Tris- $\mathrm{HCl}, 5 \mathrm{mM}$ EDTA, $5 \mathrm{mM} \mathrm{MgCl}_{2}, 1 \% \mathrm{BSA}, 30 \mu \mathrm{g} / \mathrm{ml}$ bacitracin, $\mathrm{pH}$ 7.4) supplemented with protease inhibitors as mentioned above. Binding reactions were performed in siliconized polypropylene tubes (Sigma) where the non-specific binding of [125I]JV-1-42 to the assay tubes was less than $5 \%(30,32)$. After $1 \mathrm{~h}$ of incubation at room temperature the tubes were immersed to ice-water, $250 \mu 1$ of the suspension was transferred into cold siliconized polypropylene microfuge tubes (Sigma), and centrifuged at $12,000 \mathrm{x} \mathrm{g}$ for $2 \mathrm{~min}($ Beckman $\mathrm{J} 2-21 \mathrm{M})$ at $4^{\circ} \mathrm{C}$, the supernatant being removed by aspiration. The pellet was washed twice with $500 \mu 1$ ice-cold binding buffer and then the bottoms of the tubes, containing the pellet, were cut off and counted in a gamma counter at $75 \%$ efficiency (Micromedic Systems, Huntsville, AL). Receptor binding affinity of GH-RH antagonist JV-1-38 to MNNG/HOS tumor membranes was measured in displacement experiments based on competitive inhibition of [ $\left.{ }^{125} \mathrm{I}\right] \mathrm{JV}-1-42$ binding, using various concentrations of JV-1-38 $\left(10^{-12}-10^{-6} \mathrm{M}\right)$. $\mathrm{IC}_{50}$ value was calculated with a computerized curve fitting program and is defined as the concentration of JV-1-38 causing a 50\% inhibition of $\left[{ }^{125} \mathrm{I}\right]-$ JV-1-42 binding.

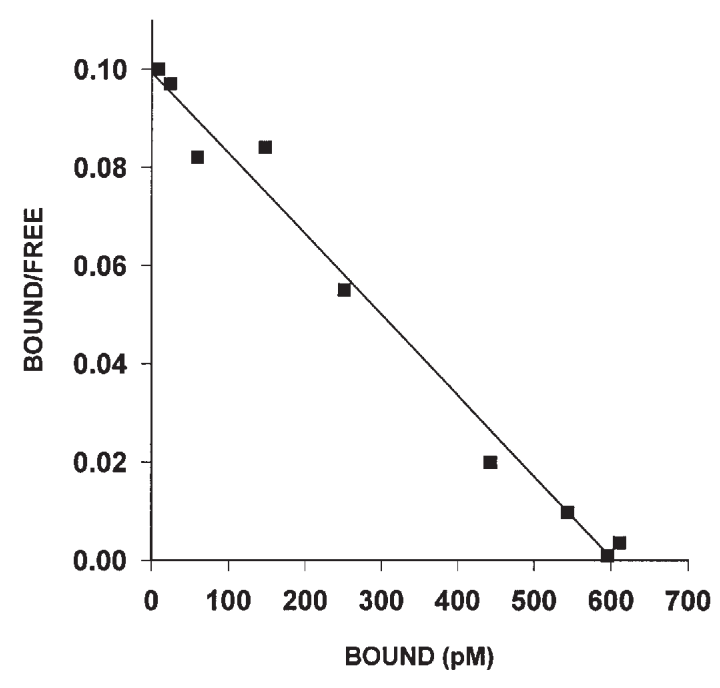

Figure 1. Representative Scatchard plot of [125] JV-1-42 binding to the membrane fraction isolated from MNNG/HOS human osteosarcoma. Specific binding was determined as described. Each point represents the mean of triplicate determinations.

Analysis of experimental data. Specific ligand-binding capacities and affinities were calculated by the Ligand-PC computerized curve-fitting program of Munson and Rodbard (37). To determine the types of receptor binding, equilibrium dissociation constants ( $\mathrm{K}_{\mathrm{d}}$ values), and the maximal binding capacity of receptors $\left(\mathrm{B}_{\max }\right), \mathrm{GH}-\mathrm{RH}$ binding data were also analyzed by the Scatchard method (38). Statistical analyses were performed using a computer software (SigmaStat, Jandel, San Rafael, CA).

\section{Results}

GH-RH receptor binding studies. The presence of specific GH-RH binding sites and characteristics of binding of ${ }^{125} \mathrm{I}-$ labeled GH-RH antagonist JV-1-42 to membrane receptors on human malignant bone tumors were determined using ligand competition assays. Analyses of the typical displacement of radiolabeled JV-1-42 by the same unlabeled peptide revealed that the one-site model provided the best fit, indicating the presence of one class of high-affinity GH-RH receptors in crude membranes of MNNG/HOS and SK-ES-1 cancers. The computerized non-linear curve fitting and the Scatchard plot analyses of the binding data (Fig. 1) in MNNG/HOS tumors indicated that the single class of high-affinity binding sites had a mean dissociation constant $\left(\mathrm{K}_{\mathrm{d}}\right)$ of $5.83 \mathrm{nM}$ with a mean maximal binding capacity $\left(\mathrm{B}_{\max }\right)$ of $552.1 \mathrm{fmol} / \mathrm{mg}$ of membrane protein (Table I). One class of low capacity, highaffinity binding sites for GH-RH was also found in the membrane fractions of SK-ES-1 tumors with a mean $\mathrm{K}_{\mathrm{d}}$ of $2.76 \mathrm{nM}$ and a mean $\mathrm{B}_{\max }$ of $371.9 \mathrm{fmol} / \mathrm{mg}$ membrane protein (Table I). Biochemical parameters essential to establish the identity of specific binding sites were determined. Thus the binding of [125I]JV-1-42 was found to be reversible, time- and temperature-dependent and linear with protein concentration to human sarcoma tissues examined (data not shown). The specificity of GH-RH binding was demonstrated by competitive binding experiments using several peptides structurally related or unrelated to GH-RH. The binding of radiolabeled JV-1-42 
Table I. Binding characteristics of GH-RH receptors in human sarcomas grown in nude mice before and after treatment with GH-RH antagonist JV-1-38 on the affinity and concentration of GH-RH receptors in membranes of MNNG/HOS human osteosarcomas.

\begin{tabular}{lcccccc}
\hline & \multicolumn{2}{c}{ MNNG/HOS } & & \multicolumn{2}{c}{ SK-ES-1 } \\
\cline { 2 - 3 } \cline { 6 - 7 } Treatment & $\begin{array}{c}\mathrm{K}_{\mathrm{d}} \\
(\mathrm{nM})\end{array}$ & $\begin{array}{c}\mathrm{B}_{\max }(\mathrm{fmol} / \\
\mathrm{mg} \text { protein })\end{array}$ & & $\begin{array}{c}\mathrm{K}_{\mathrm{d}} \\
(\mathrm{nM})\end{array}$ & $\begin{array}{c}\mathrm{B}_{\max } \text { (fmol/ } \\
\text { mg protein) }\end{array}$ \\
\hline Control & $5.83 \pm 0.91$ & $552.1 \pm 32.7$ & & $2.76 \pm 0.75$ & $371.9 \pm 44.1$ \\
JV-1-38 & $5.41 \pm 1.03$ & $504.8 \pm 70.9$ & & n.i. & n.i. \\
\hline
\end{tabular}

Binding characteristics were obtained from 12-point displacement experiments. All values represent mean \pm SE of 3-4 independent experiments, each done in duplicate or triplicate tubes. $\mathrm{K}_{\mathrm{d}}$, dissociation constant; $\mathrm{B}_{\max }$, maximal binding capacity; n.i., not investigated.

was completely displaced by increasing concentrations $\left(10^{-12}\right.$ $10^{-6} \mathrm{M}$ ) of GH-RH and its analogs. None of the structurally and functionally unrelated peptides tested such as somatostatin, luteinizing hormone-releasing hormone, epidermal growth factor, $\left[\mathrm{Tyr}^{4}\right]$ bombesin and IGF-I inhibited the binding of [125I]JV-1-42 at concentrations as high as $1 \mu \mathrm{M}$ (data not shown).

The concentration of unlabeled GH-RH antagonist JV-1-38 required to inhibit $50 \%$ of the specific [ $\left.{ }^{125} \mathrm{I}\right] \mathrm{JV}-1-42$ binding $\left(\mathrm{IC}_{50}\right)$ was $1.04 \pm 0.72 \mathrm{nM}$ (Fig. 2). This $\mathrm{IC}_{50}$ value of JV-1-38 represents a high binding affinity to $\mathrm{GH}-\mathrm{RH}$ receptor protein expressed on MNNG/HOS human osteosarcomas.

PCR analyses of splice variants of GH-RH receptors in $M N N G / H O S$ and SK-ES-1 human sarcomas. To investigate whether high-affinity binding sites for GH-RH present in the membranes of human sarcomas grown in nude mice are the products of mRNA expression of GH-RH receptors, we performed RT-PCR analysis. In both human malignant bone cancer lines, reverse transcription of RNA, followed by nested PCR amplification with specific primers corresponding to intron 3 and exon 12 of the hGH-RH receptor gene in the primary PCR, and primers designed from intron 3 and exon 8 in the secondary PCR, amplified 720- and 566-bp PCR products (Fig. 3). Sequence analyses of these two PCR fragments revealed different major open reading frames, which corresponded to SV1 and SV2 of the GH-RH receptor described previously (31). No bands representing splice variants SV3 and SV4 were obtained. Negative controls yielded no detectable signals, indicating that PCR products were generated from cDNA and not from genomic DNA or contamination. PCR amplification with human B-actin specific primers produced a single product of $459 \mathrm{bp}$ from all samples, confirming that no RNA degradation occurred during the preparations (data not shown).

Characteristics of receptors for $G H-R H$ in $M N N G / H O S$ human osteosarcomas after chronic treatment with $\mathrm{GH}-\mathrm{RH}$

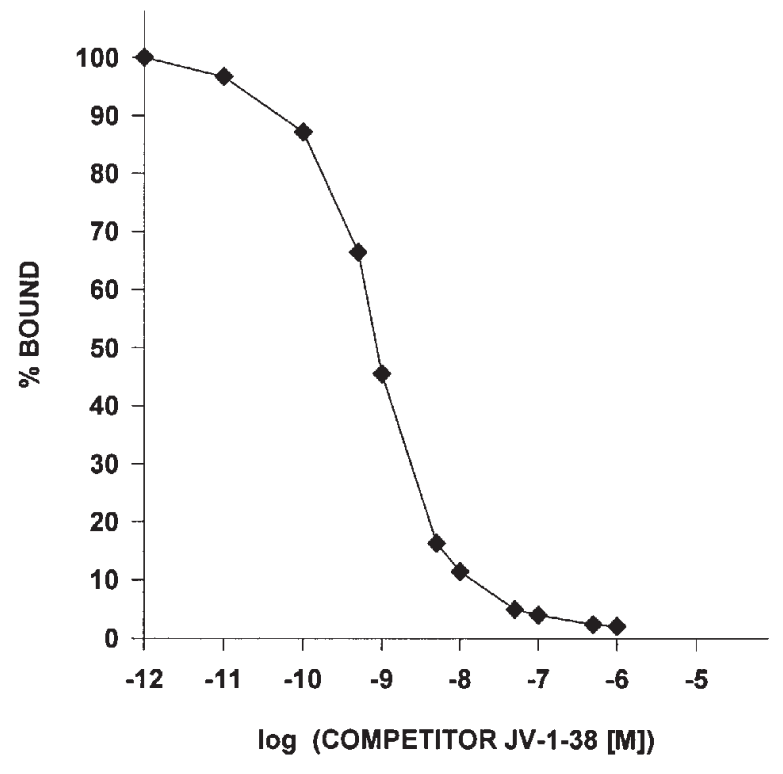

Figure 2. Representative displacement of [ $\left.{ }^{125} \mathrm{I}\right] \mathrm{JV}-1-42$ binding to the membrane fraction isolated from MNNG/HOS human osteosarcoma by increasing concentrations of GH-RH antagonist JV-1-38 ( $)$. One hundred percent specific binding is defined as the difference between binding in the absence and that in the presence of $10^{-5} \mathrm{M} J \mathrm{~J}-1-42$. Each point represents the mean of triplicate determinations

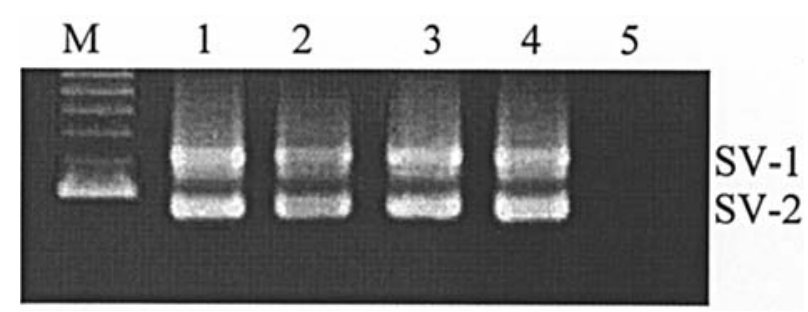

Figure 3. Representative RT-PCR analysis of the expression of mRNA for $\mathrm{SVs}$ of GH-RH receptors in MNNG/HOS human osteosarcomas grown in nude mice. The products were of the expected size of $720 \mathrm{bp}$ corresponding to SV1 and 566 bp corresponding to SV2. Lane M, 100-bp DNA molecular weight marker; lanes 1 and 2, control (untreated) MNNG/HOS tumors; lanes 3 and 4, JV-1-38 treated MNNG/HOS tumors; lane 5, negative control.

antagonist $J V-1-38$. The presence of specific, high affinity receptors for $\mathrm{GH}-\mathrm{RH}$ in membrane fractions of MNNG/HOS osteosarcomas was also detected 4 weeks after treatment with GH-RH antagonist JV-1-38. After daily administration of JV-1-38 for 28 days, there were no significant changes in the binding affinities and the capacities of the GH-RH receptors in mice with MNNG/HOS tumors (Table I). Thus, chronic treatment with GH-RH antagonist JV-1-38 did not affect the binding characteristics of receptors for GH-RH in MNNG/ HOS human osteosarcoma.

RT-PCR analyses revealed the presence of 720-bp and 566-bp products corresponding to SV1 and SV2 of the GH-RH receptor in MNNG/HOS tumors after treatment with GH-RH antagonist JV-1-38. Semiquantitative analysis showed that daily injections of JV-1-38 did not significantly alter the mRNA levels of SV1 and SV2 of GH-RH receptors (Fig. 3).

\section{Discussion}

New therapeutic modalities are needed to improve the treatment of patients with osteogenic sarcomas and other 
malignant bone tumors. For our study we selected the MNNG/ HOS, a chemically transformed cell line derived from an osteogenic sarcoma of a 13-year-old Caucasian female and SK-ES-1 line, established from Ewing's sarcoma to represent malignant human bone tumors $(35,36)$. Both of these sarcomas are well characterized and known to proliferate in vitro and to develop tumors in athymic nude mice $(3,29,35,36)$.

In a previous study in nude mice bearing MNNG/HOS osteosarcomas and SK-ES-1 Ewing's sarcomas, the treatment with GH-RH antagonist JV-1-38 significantly inhibited the tumor volume and weight, and reduced the concentration of tumoral IGF-II and its gene expression (3). In proliferation studies in vitro, the growth of MNNG/HOS and SK-ES-1 cells was dose-dependently inhibited by JV-1-38 and an antiserum against human GH-RH (29). In addition, RT-PCR analyses showed the presence of mRNA for GH-RH, which is apparently translated into the GH-RH peptide and secreted by the sarcoma cells (29).

It has been known for more than two decades that some cancers produce GH-RH (39). Recent studies also indicate that this peptide is an autocrine growth factor for many malignancies. Thus, it was shown that various cancer lines including human bone, breast, endometrial, ovarian, pancreatic, gastric, colorectal and lung cancers synthesize GH-RH and their growth is stimulated by exogenous GH-RH and its agonistic analogs $(20,26,27,29,33,40-42)$. mRNA for GH-RH or GH-RH peptide have also been demonstrated in surgical specimens of human pancreatic, lung, prostatic, breast, ovarian, endometrial, adrenal and pituitary tumors $(2,32,39,41,43-45)$.

Initial attempts to detect the tumoral receptors that can mediate the direct effects of GH-RH and its antagonists were unsuccessful, since the pituitary-type GH-RH receptor is not expressed in a number of human breast, ovarian, prostatic, SCLC, pancreatic and renal cancer models $(2,11,30,31)$. However, we were able to demonstrate by the isolation and sequencing of corresponding cDNA that these and other tumors, including primary human prostate cancers express the mRNAs for four SVs of GH-RH receptor (30-32). Radioligand binding studies using GH-RH antagonist JV-1-42 (30) as a special ligand, revealed the presence of tumoral binding sites for GH-RH with characteristics different from the pituitary receptors (30-32). These SVs of GH-RH receptors on tumors might mediate the direct effects of GH-RH and its antagonists and are distinct from the pituitary-type GH-RH receptors or receptors for other peptides of the vasoactive intestinal peptide/ secretin/glucagon family (2,30-32). All of the SVs of the GH-RH receptor have a retained intronic sequence at the 5'end, but lack the first three exons $(30,31)$. The deduced protein sequence of SV1 differs from the pituitary GH-RH receptor only in the N-terminal extracellular domain, the first 89 amino acids of the pituitary GH-RH receptor being replaced by a different, 25-amino acid sequence (31). Thus, receptor SV1 would encode a functional G-protein coupled receptor with a 7 transmembrane domain. SV2 may encode a GH-RH receptor isoform truncated after the second transmembrane domain (31). The participation of SV1 in cell proliferation signaling has been shown by transfection in NIH-3T3 mouse fibroblast cells (34). In that study, transfection of 3T3 cells with SV1 produced specific high affinity binding sites for radiolabeled GH-RH antagonist JV-1-42 and conferred a greatly augmented sensitivity to GH-RH analogs. Thus, the expression of SV1 increased the mitogenic responses to GH-RH or GH-RH agonist JI-38 and the antimitogenic response to GH-RH antagonist JV-1-38, compared with control 3T3 cells, which did not express SV1 (34).

To confirm that mRNA for SV1 is translated into a corresponding GH-RH receptor isoform protein, we developed a polyclonal antiserum generated against the N-terminal 25amino acid sequence which is present in SV1, but not in the pituitary GH-RH receptor (46). The specificity and sensitivity of the antisera were studied on xenografts of RL and HT human non-Hodgkin's lymphomas (46). Using these antisera $\mathrm{SV}$-specific immunostaining or Western blot signals, consistent with the expected molecular mass of $40 \mathrm{kDa}$ of SV1 protein were detected in RL and HT lymphomas as well as in surgical specimens of breast cancers $(43,46)$. RT-PCR and ligand binding studies also revealed the expression of SV1 and the presence of high affinity binding sites for GH-RH on RL and HT tumors (46).

Lately, we re-investigated whether human tumors can express the pituitary GH-RH receptors (47). Thus, we developed a real-time PCR method with new primers for the detection of mRNA of the pituitary GH-RH receptors, its SVs and the GH-RH peptide (47). Using this real-time PCR method, Western blots and radioligand binding assays with antibodies and ligands specific for the pituitary GH-RH receptors, we showed that the mRNA for pituitary-type receptor and its receptor protein are detectable in human lymphoma, glioblastoma and SCLC cell lines grown in nude mice and in surgical specimens of human lung cancers (47). Since various tumors can express not only the SVs, but also the pituitary GH-RH receptors, both types of GH-RH receptors could play an important role in the pathophysiology of human cancers.

The current study reports the presence of specific, high affinity receptors for $\mathrm{GH}-\mathrm{RH}$ antagonists on tumor membranes of MNNG/HOS osteosarcomas and SK-ES-1 Ewing's sarcomas. Our work also confirms and extends our previous findings (29) demonstrating the expression of mRNA for SV1 and SV2 of GH-RH receptors by these malignant bone tumors. GH-RH antagonist JV-1-38 displayed a high affinity binding to MNNG/HOS tumors characterized by an $\mathrm{IC}_{50}$ value of $1.04 \mathrm{nM}$. These in vitro findings are supported by the results in vivo. Administration of antagonist JV-1-38 significantly inhibited the tumor volume and tumor weight of MNNG/HOS and SK-ES-1 tumors by more than $50 \%$ after 4 weeks and significantly prolonged tumor doubling time (3). Another aim of the present study was also to examine whether GH-RH antagonist JV-1-38 administered s.c. at a dose of $20 \mu \mathrm{g}$ twice daily for 4 weeks would affect the gene expression and binding characteristics of receptors for GH-RH on cell membranes of MNNG/HOS tumors. Our results show that chronic treatment with GH-RH antagonist JV-1-38 did not affect the affinity, concentration and mRNA expression of receptors for GH-RH in MNNG/HOS human osteosarcomas as compared with controls. This study is the first to reveal that daily administration of a potent $\mathrm{GH}-\mathrm{RH}$ antagonist, even at a relatively high dose, does not down-regulate the GH-RH receptors on tumor cells as in the classical case of LHRH receptors following repeated treatment with LHRH agonists. 
In conclusion, our study supports the merit of development of GH-RH antagonists for the therapy of patients with malignant bone tumors and other cancers.

\section{Acknowledgements}

This work was supported by the Medical Research Service of the Veterans Affairs Department and a grant from ZENTARIS Gmbh (Frankfurt am Main, Germany) to Tulane University (all to A.V.S.). We thank Dr Ryszard Braczkowski for participation in the oncological part of this work.

\section{References}

1. Whelan JS: Osteosarcoma. Eur J Cancer 33: 1611-1119, 1997.

2. Schally AV, Comaru-Schally AM, Nagy A, Kovacs M, Szepeshazi K, Plonowski A, Varga JL and Halmos G: Hypothalamic hormones and cancer. Front Neuroendocrinol 22: 248-291, 2001

3. Braczkowski R, Schally AV, Plonowski A, Varga JL, Groot K, Krupa $\mathrm{M}$ and Armatis P: Inhibition of proliferation in human MNNG/HOS osteosarcoma and SK-ES-1 Ewing's sarcoma cell lines in vitro and in vivo by antagonists of growth hormonereleasing hormone: effects on IGF-II. Cancer 95: 1735-1745, 2002.

4. Ferrari S, Bacci G, Picci P, et al: Long-term follow-up and postrelapse survival in patients with non-metastatic osteosarcoma of the extremity treated with neoadjuvant chemotherapy. Ann Oncol 8: 765-771, 1997

5. Saeter G, Hoie J, Stenwig AE, Johansson AK, Hannisdal E and Solheim OP: Systemic relapse of patients with osteogenic sarcoma. Prognostic factors for long term survival. Cancer 75 1084-1093, 1995.

6. Rosen G: Bone tumors. In: Cancer Medicine. Kufe DW, Pollock RE, Weichselbaum RR, Bast RC Jr, Gansler TS, Holland JF and Frei E III (eds). 6th edition. B.C. Dekker Publishers, Hamilton, Ontario, pp99-104, 2004.

7. Togari A, Arai M, Mizutani S, Mizutani S, Koshihara Y and Nagatsu T: Expression of mRNAs for neuropeptide receptors and beta-adrenergic receptors in human osteoblasts and human osteogenic sarcoma cells. Neurosci Lett 233: 125-128, 1997.

8. Benini S, Baldini N, Manara MC, et al: Redundancy of autocrine loops in human osteosarcoma cells. Int J Cancer 80: 581-588, 1999.

9. Khandwala HM, McCutcheon IE, Flyvbjerg A and Friend KE: The effects of insulin-like growth factors on tumorigenesis and neoplastic growth. Endocr Rev 21: 215-244, 2000.

10. Pinski J, Schally AV, Groot K, Halmos G, Szepeshazi K, Zarandi M and Armatis P: Inhibition of growth of human osteosarcomas by antagonists of growth hormone-releasing hormone. J Natl Cancer Inst 87: 1787-1794, 1995.

11. Schally AV and Varga JL: Antagonistic analogs of growth hormone-releasing hormone: new potential antitumor agents. Trends Endocrinol Metab 10: 383-391, 1999.

12. Zarandi M, Horvath JE, Halmos G, Pinski J, Nagy A, Groot K and Rekasi Z: Synthesis and biological activities of highly potent antagonists of growth hormone-releasing hormone. Proc Natl Acad Sci USA 91: 12298-12302, 1994.

13. Varga JL, Schally AV, Csernus VJ, Zarandi M, Halmos G and Rekasi Z: Synthesis and biological evaluation of antagonists of GH-RH with high and protracted in vivo activities. Proc Natl Acad Sci USA 96: 692-697, 1999.

14. Varga JL, Schally AV, Horvath JE, et al: Increased activity of antagonists of growth hormone-releasing hormone substituted at positions 8, 9 and 10. Proc Natl Acad Sci USA 101: 1708-1713, 2004.

15. Szepeshazi K, Schally AV, Groot K, Armatis P, Hebert F and Halmos G: Antagonists of growth hormone-releasing hormone (GH-RH) inhibit in vivo proliferation of experimental pancreatic cancers and decrease IGF-II levels in tumors. Eur J Cancer 36: 128-136, 2000

16. Szepeshazi K, Schally AV, Groot K, et al: Antagonists of growth hormone-releasing hormone (GH-RH) inhibit IGF-II production and growth of HT-29 human colon cancers. Br J Cancer 82: 1724-1731, 2000.
17. Jungwirth A, Schally AV, Pinski J, Halmos G, Groot K, Armatis $\mathrm{P}$ and Vadillo-Buenfil M: Inhibition of in vivo proliferation of androgen-independent prostate cancers by an antagonist of growth hormone-releasing hormone. Br J Cancer 75: 1585-1592, 1997.

18. Lamharzi N, Schally AV, Koppan M and Groot K: Growth hormone-releasing hormone antagonist MZ-5-156 inhibits growth of DU-145 human androgen-independent prostate carcinoma in nude mice and suppresses the levels and mRNA expression of insulin like growth factor II in tumors. Proc Natl Acad Sci USA 95: 8864-8868, 1998

19. Letsch M, Schally AV, Busto R, Bajo AM and Varga JL: Growth hormone-releasing hormone (GH-RH) antagonists inhibit the proliferation of androgen-dependent and -independent prostate cancers. Proc Natl Acad Sci USA 100: 1250-1255, 2003.

20. Kahan Z, Varga JL, Schally AV, et al: Antagonists of growth hormone releasing hormone arrest the growth of MDA-MB-468 estrogen-independent human breast cancers in nude mice. Breast Cancer Res Treat 60: 71-79, 2000.

21. Chatzistamou I, Schally AV, Varga JL, Groot K, Busto R, Armatis P and Halmos G: Inhibition of growth and metastases of MDA-MB-435 human estrogen-independent breast cancers by an antagonist of growth hormone-releasing hormone. Anticancer Drugs 12: 761-768, 2001.

22. Chatzistamou I, Schally AV, Varga J, Groot K, Armatis P and Bajo AM: Inhibition of growth and reduction in tumourigenicity of UCI-107 ovarian cancer by antagonists of growth hormonereleasing hormone and vasoactive intestinal peptide. J Cancer Res Clin Oncol 127: 645-652, 2001.

23. Jungwirth A, Schally AV, Pinski J, Groot K and Halmos G: Growth hormone-releasing hormone antagonist MZ-4-71 inhibits in vivo proliferation of Caki-I renal adenocarcinoma. Proc Natl Acad Sci USA 94: 5810-5812, 1997.

24. Kiaris H, Schally AV and Varga JL: Antagonists of growth hormone-releasing hormone inhibit the growth of U-87MG human glioblastoma in nude mice. Neoplasia 2: 242-250, 2000.

25. Pinski J, Schally AV, Jungwirth A, et al: Inhibition of growth of human small-cell and non-small-cell lung carcinomas by antagonists of growth hormone-releasing hormone (GH-RH). Int J Oncol 9: 1099-1105, 1996.

26. Kiaris H, Schally AV, Varga JL, Groot K and Armatis P: Growth hormone-releasing hormone: an autocrine growth factor for small cell lung carcinoma. Proc Natl Acad Sci USA 96: 14894-14898, 1999.

27. Szereday Z, Schally AV, Varga JL, et al: Antagonists of growth hormone-releasing hormone inhibit the proliferation of experimental non-small cell lung carcinoma. Cancer Res 63: 7913-7919, 2003

28. Rekasi Z, Varga JL, Schally AV, Halmos G, Armatis P, Groot K and Czompoly T: Antagonists of growth hormone-releasing hormone and vasoactive intestinal peptide inhibit tumor proliferation by different mechanisms: evidence from in vitro studies on human prostatic and pancreatic cancers. Endocrinology 141: 2120-2128, 2000.

29. Busto R, Schally AV, Braczkowski R, et al: Expression of mRNA for growth hormone-releasing hormone and splice variants of GHRH receptors in human malignant bone tumors. Regul Pept 108: 47-53, 2002.

30. Halmos G, Schally AV, Varga JL, Plonowski A, Rekasi Z and Czompoly T: Human renal cell carcinoma expresses distinct binding sites for growth hormone-releasing hormone. Proc Natl Acad Sci USA 97: 10555-10560, 2000.

31. Rekasi Z, Czompoly T, Schally AV and Halmos G: Isolation and sequencing of cDNAs for splice variants of growth hormonereleasing hormone receptors from human cancers. Proc Natl Acad Sci USA 97: 10561-10566, 2000.

32. Halmos G, Schally AV, Czompoly T, Krupa M, Varga JL and Rekasi Z: Expression of growth hormone-releasing hormone and its receptor splice variants in human prostate cancer. J Clin Endocrinol Metab 87: 4707-4714, 2002.

33. Busto R, Schally AV, Varga JL, Garcia-Fernandez MO, Groot K, Armatis $\mathrm{P}$ and Szepeshazi K: The expression of growth hormonereleasing hormone $(\mathrm{GHRH})$ and splice variants of its receptor in human gastroenteropancreatic carcinomas. Proc Natl Acad Sci USA 99: 11866-11871, 2002

34. Kiaris H, Schally AV, Busto R, Halmos G, Artavanis-Tsakonas S and Varga JL: Expression of a splice variant of the receptor for GHRH in 3T3 fibroblasts activates cell proliferation responses to GHRH analogs. Proc Natl Acad Sci USA 99: 196-200, 2002 . 
35. Rhim JS, Park DK, Arnstein P, Huebner RJ, Weisburger EK and Nelson-Rees WA: Transformation of human cells in culture by N-methyl-N'-nitro-N-nitrosoguanidine. Nature 256: 751-753, 1975.

36. Bloom ET: Further definition by cytotoxicity tests of cell surface antigens of human sarcomas in culture. Cancer Res 32: 960-967, 1972.

37. Munson PJ and Rodbard D: Ligand: a versatile computerized approach for characterization of ligand-binding systems. Anal Biochem 107: 220-239, 1980.

38. Scatchard B: The attraction of proteins for small molecules and ions. Ann NY Acad Sci 51: 660-662, 1949.

39. Frohman LA and Szabo M: Ectopic production of growth hormone-releasing factor by carcinoid and pancreatic islet tumors associated with acromegaly. Prog Clin Biol Res 74: 259-271, 1981.

40. Plonowski A, Schally AV, Busto R, Krupa M, Varga JL and Halmos G: Expression of growth hormone-releasing hormone (GHRH) and splice variants of GHRH receptors in human experimental prostate cancers. Peptides 23: 1127-1133, 2002.

41. Kahan Z, Arencibia J, Csernus V, Groot K, Kineman R, Robinson WR and Schally AV: Expression of growth hormonereleasing hormone $(\mathrm{GHRH})$ messenger ribonucleic acid and the presence of biologically active GHRH in human breast, endometrial, and ovarian cancers. J Clin Endocrinol Metab 84: $582-589,1999$.
42. Garcia-Fernandez MO, Schally AV, Varga JL, Groot K and Busto R: The expression of growth hormone-releasing hormone $(\mathrm{GHRH})$ and its receptor splice variants in human breast cancer lines; the evaluation of signaling mechanisms in the stimulation of cell proliferation. Breast Cancer Res Treat 77: 15-26, 2003.

43. Chatzistamou I, Schally AV, Kiaris H, et al: Immunohistochemical detection of growth hormone-releasing hormone and its receptor splice variant 1 in primary human breast cancers. Eur J Endocrinol 151: 391-396, 2004.

44. Khorram O, Garthwaite M, Grosen E and Golos T: Human uterine and ovarian expression of growth hormone-releasing hormone messenger RNA in benign and malignant gynecologic conditions. Fertil Steril 75: 174-179, 2001.

45. Losa M, Wolfram G, Mojto J, et al: Presence of growth hormonereleasing hormone-like immunoreactivity in human tumors: characterization of immunological and biological properties. J Clin Endocrinol Metab 70: 62-68, 1990.

46. Toller GL, Horvath JE, Schally AV, et al: Development of a polyclonal antiserum for the detection of the isoforms of the receptors for human growth hormone-releasing hormone on tumors. Proc Natl Acad Sci USA 101: 15160-15165, 2004.

47. Havt A, Schally AV, Halmos G, et al: The expression of the pituitary GHRH receptor and its splice variants in normal and neoplastic human tissues. Proc Natl Acad Sci USA 102: 17424-17429, 2005 